\title{
Strategies to prevent spread of Leptosphaeria maculans (phoma stem canker) onto oilseed rape crops in China; costs and benefits
}

\author{
B. D. L. Fitt ${ }^{a \star}$, B. C. Hu ${ }^{b}$, Z. Q. Li ${ }^{\mathrm{c}}$, S. Y. Liu ${ }^{\mathrm{d}}$, R. M. Lange ${ }^{\mathrm{e}}$, P. D. Kharbanda ${ }^{\mathrm{e}}$, \\ M. H. Butterworth ${ }^{a}$ and R. P. White ${ }^{a}$ \\ ${ }^{a}$ Rothamsted Research, Harpenden, AL5 2JQ, UK; ${ }^{b}$ Crop Research Institute, Anhui Academy of Agricultural Sciences, Hefei 230031; \\ ${ }^{c}$ Plant Protection Institute, Inner Mongolia Academy of Agricultural Sciences, Huhhot 010031; 'Oil Crops Research Institute, Chinese \\ Academy of Agricultural Sciences, Wuhan 430062, P. R. China; and ${ }^{\circ}$ Alberta Research Council, Post Office Bag 4000, Vegreville, \\ AB T9C IT4, Canada
}

Field experiments in Europe have shown that Chinese cultivars of winter oilseed rape (Brassica napus) are very susceptible to the pathogen Leptosphaeria maculans (cause of phoma stem canker). Climatic and agronomic conditions in China are suitable for L. maculans since the closely related but less damaging pathogen L. biglobosa occurs on the winter and spring oilseed rape crops there. Major gene resistance to L. maculans is not durable; when introduced into commercial oilseed rape cultivars it is rapidly rendered ineffective by changes in the pathogen population. The threat to Chinese oilseed rape production from $L$. maculans is illustrated by the way in which $L$. maculans has spread into other areas of the world where previously only L. biglobosa was present, such as Canada and Poland. Models were developed to describe the spread (in space and time) of $L$. maculans across Alberta province, Canada, based on survey data collected over a 15 -year period. These models were used to estimate the potential spread of L. maculans across the Yangtze river oilseed rape growing areas of China and its associated costs. Short-term strategies to prevent occurrence of severe phoma stem canker epidemics in China include training of extension workers to recognise symptoms of the disease and use of PCR-based diagnostics to detect the pathogen on imported seed. Long-term strategies include the introduction of durable resistance to L. maculans into Chinese oilseed rape cultivars as a component of an integrated disease management programme. The costs of such strategies in relation to costs of a phoma stem canker epidemic are discussed.

Keywords: cost-benefit analysis, durable disease resistance, global invasive species, PCR-based diagnostics, spatio-temporal epidemic spread

\section{Introduction}

Phoma stem canker (blackleg) is an internationally important disease of oilseed rape (Brassica napus, canola, rapeseed) (Fitt et al., 2006a,b) and vegetable brassicas (Rimmer \& van den Berg, 2007). On oilseed rape, it causes serious losses in Europe, Australia and North America; worldwide losses are estimated at > US\$900M per growing season. There is evidence that the pathogens causing phoma stem canker are adaptable, since the disease is very damaging on both spring and winter (autumn-sown) types of oilseed rape in a wide range of climates (West et al., 2001). Phoma stem canker

*E-mail: bruce.fitt@bbsrc.ac.uk

Published online 23 March 2008 pathogen populations comprise two main species, Leptosphaeria maculans, associated with damaging stem base cankers, and L. biglobosa, often associated with less damaging upper stem lesions (Rouxel \& Balesdent, 2005). To date, phoma stem canker (Fig. 1a,b) has not been a serious problem in China and only the less aggressive L. biglobosa has been found there (Fitt et al., 2006a). Whilst the first record of phoma stem canker in China (West et al., 2000) described the pathogen as L. maculans, subsequently the B-type of L. maculans has been named L. biglobosa (Shoemaker \& Brun, 2001) and unpublished work using species-specific PCR (Liu et al., 2006) has showed that all Chinese isolates obtained to date are L. biglobosa. However, the two related Leptosphaeria species occupy similar ecological niches (Fitt et al., 2006c), which suggests that climate and agronomic conditions in China are also suitable for the more damaging, closely 

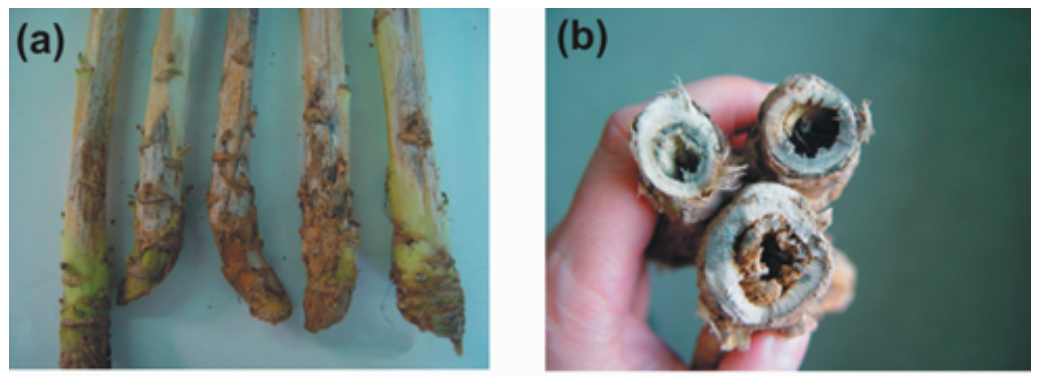

(c)

Figure 1 Phoma stem canker on Chinese winter oilseed rape cultivars. Canker symptoms associated with leaf scars on the stem base externally (a) and in cross-section (b) of plants affected by Leptosphaeria biglobosa, sampled at Hefei, Anhui Province, China on 29 May 2006. (c) Plot of Chinese cv. Ningyou 7 showing premature senescence caused by stem base cankers produced by L. maculans, by comparison with a plot of $\mathrm{cv}$. Tapidor, a susceptible European cultivar, at Spalding, Lincolnshire, UK on 16 June 2006.

related species L. maculans. Since many Chinese oilseed rape cultivars are highly susceptible to $L$. maculans when they are grown in the UK (Fig. 1c) or France (Fitt et al., 2006a), this raises the concern that considerable damage could result if L. maculans becomes established in China. Furthermore, if major gene resistance to L. maculans is exploited in widely grown commercial cultivars, it is rapidly rendered ineffective by changes in the pathogen population (Sprague et al., 2006).

There is evidence that the life cycles of L. maculans and L. biglobosa are similar (West et al., 2002a; Fitt et al., 2006c). Both pathogens produce airborne ascospores in pseudothecia on crop debris (West et al., 2001, 2002b; Huang et al., 2005). The timing of ascospore release is affected by temperature and rainfall during the period of pseudothecial maturation on the crop debris (ToscanoUnderwood et al., 2003; Evans et al., 2008; Huang et al., 2007). Ascospores of both species landing on oilseed rape leaves germinate and produce germ tubes that penetrate leaf surfaces through stomata (Huang et al., 2001, 2003a). The pathogens then grow in leaf tissues and produce phoma leaf spot lesions; lesions caused by $L$. maculans are beige-coloured with numerous black pycnidia, whereas lesions caused by L. biglobosa are smaller and darker, with few pycnidia (Williams \& Fitt, 1999). The length of the incubation period between infection and appearance of lesions is affected by temperature (Biddulph et al., 1999; Toscano-Underwood et al., 2001). Subsequently both pathogens grow symptomlessly along leaf petiole tissues to reach the stem, where stem cankers are formed (West et al., 2002a; Fitt et al., 2006c). The time from the appearance of phoma leaf spot lesions to the appearance of stem cankers is dependent on accumulated temperature $\left({ }^{\circ} \mathrm{C}\right.$-days $)$ and cultivar resistance (Sun et al., 2001; Evans et al., 2008). The severity of stem cankers before harvest is also dependent on the accumulated temperature from the time that cankers first appear and cultivar resistance. After harvest, both L. maculans and L. biglobosa survive on crop (especially stem) debris, where pseudothecia are produced (Huang et al., 2003b).

China has the largest cultivated brassica area in the world; there are $c a .8 \mathrm{M}$ ha of oilseed rape (B. napus) and ca. $2 \mathrm{M}$ ha of brassica vegetables (usually Brassica rapa) grown annually (Fig. 2), mainly by subsistence farmers (Fig. 3). The oilseed rape is mostly winter type B. napus grown along the Yangtze river basin and in southern China (7M ha), where it is usually sown in October and harvested in May (mean temperature $13 \cdot 3^{\circ} \mathrm{C}$, total rainfall $717 \mathrm{~mm}$ during growing season) (Table 1). However, there is also spring type $B$. napus grown in northern China (1M ha), where it is usually sown in April and harvested in September (mean temperature $13.4^{\circ} \mathrm{C}$, total rainfall $334 \mathrm{~mm}$ during growing season). Between successive crops in northern China, the ground is left fallow during the very cold winter, whereas in the Yangtze river region, 

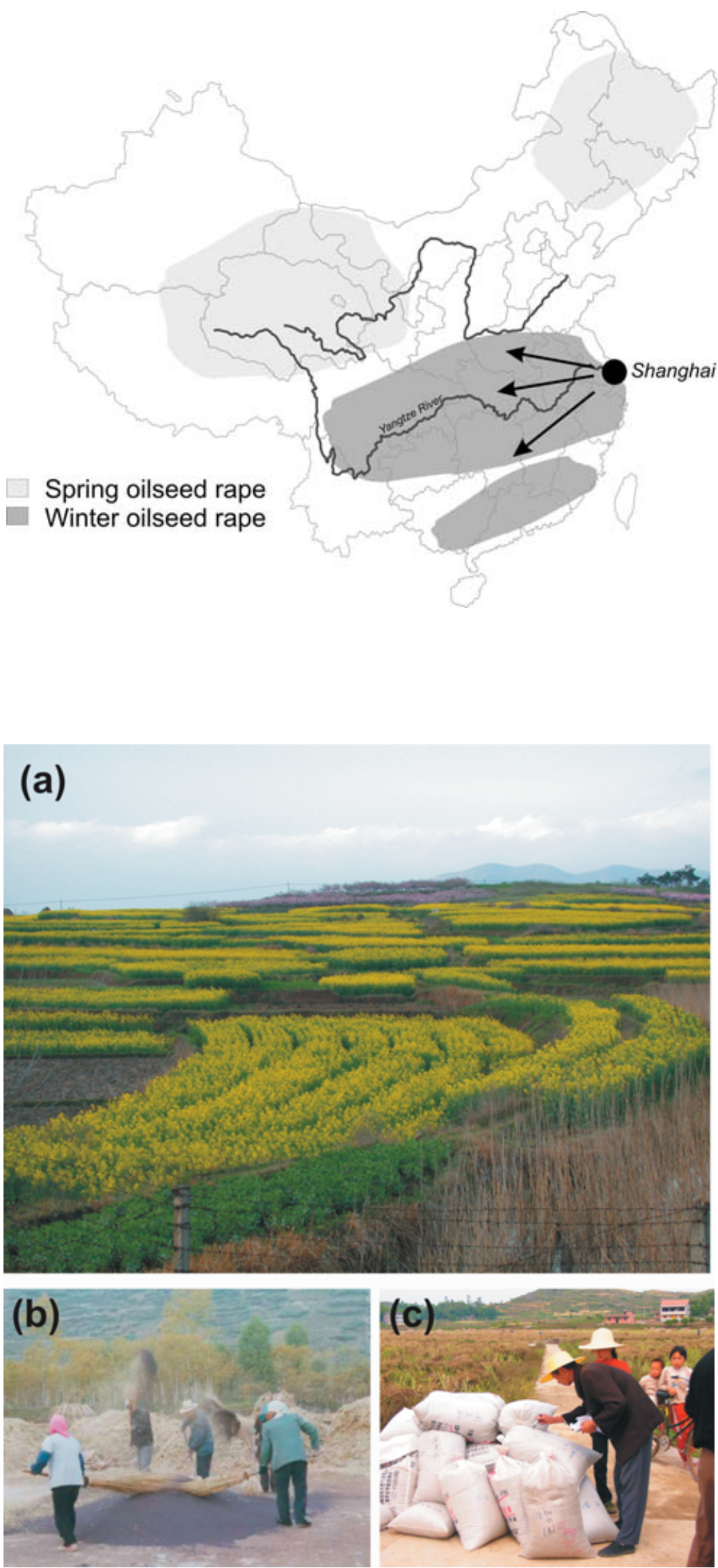

Figure 2 Oilseed-rape growing areas of China. Most intensive production is of winter oilseed rape (Brassica napus) along the Yangtze river basin (7M ha), although some is grown in south-east China. There is also $1 \mathrm{M}$ ha of spring oilseed rape grown in northern China and about 2M ha of vegetable brassicas (mostly B. rapa) grown throughout China. Modelling of potential westward spread of Leptosphaeria maculans into oilseed rape growing areas along the Yangzte river basin assumes that it is introduced into China on infected seed imported into Shanghai $(\bullet)$.
Figure 3 Production of winter oilseed rape near Wuhan, Hubei province, China. (a) small strips of crops in patches belonging to different families; (b) threshing by a family group; (c) family marking the bag of seed belonging to them. 
Table 1 Climate and agronomy of oilseed rape production in Alberta Province, Canada and northern and Yangtze river regions of China

\begin{tabular}{|c|c|c|c|}
\hline & Alberta, Canada & Northern China & Yangtze river region \\
\hline Crop type & Spring type & Spring type & Winter type \\
\hline Sowing date & 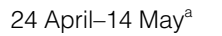 & 1 April-10 May & 20 Sept-15 Oct \\
\hline Sowing method & Drilling & Drilling or transplanting & Drilling or broadcast sowing \\
\hline Harvest date & 15 Aug-31 Oct ${ }^{b}$ & 25 Aug-10 Sept & 25 April-15 May \\
\hline Harvest method & Machine & Hand or machine & Hand \\
\hline Mean temp. (growing season) & $\begin{array}{l}4 \cdot 8-16 \cdot 3^{\circ} \mathrm{C} / \text { month }^{\mathrm{c}} \\
\left(\text { mean } 11 \cdot 1^{\circ} \mathrm{C}\right)\end{array}$ & $\begin{array}{l}2 \cdot 3-17 \cdot 5^{\circ} \mathrm{C} / \text { month }^{\dagger} \\
\left(13 \cdot 4^{\circ} \mathrm{C}\right)\end{array}$ & $\begin{array}{l}2 \cdot 4-24 \cdot 6^{\circ} \mathrm{C} / \text { month }^{\dagger} \\
\left(13 \cdot 3^{\circ} \mathrm{C}\right)\end{array}$ \\
\hline Total rainfall (growing season) & $328 \mathrm{~mm}^{\mathrm{d}}$ & $334 \mathrm{~mm}^{\mathrm{g}}$ & $717 \mathrm{~mm}^{\mathrm{g}}$ \\
\hline Prevailing wind direction (growing season) & Variable, not east & North & North-west \\
\hline Post-harvest cultivation & Various crops ${ }^{e}$ & Fallow & Rice or cotton \\
\hline
\end{tabular}

aSource of Alberta sowing date data: http://www1.agric.gov.ab.ca/\$department/deptdocs.nsf/all/crop5758, range of sowing dates for all soil types plus Peace River Region.

${ }^{b}$ Personal Communication, Mr Murray Hartman, Oilseed Specialist, Alberta Agriculture and Food, 7 December, 2007.

${ }^{\mathrm{c}}$ Range of monthly mean daily temperatures of Lethbridge, Lacombe and Beaverlodge, Alberta for April to October, 1971-2000. Source: Canadian Climate Normals, Environment Canada (http://www.climate.weatheroffice.ec.gc.ca/climate_normals/index e.html), accessed 7 December, 2007.

dTotal precipitation, including snow, for April-October, 1971-2000, average of totals for Lethbridge, Lacombe, and Beaverlodge, Alberta.

Source: http://www.climate.weatheroffice.ec.gc.ca/climate_normals/index e.html.

eTypically, wheat or barley, but can be forages, pulse crops, or even oilseed rape.

${ }^{\mathrm{f}}$ Range of monthly mean daily temperatures for Yangtze River region (represented by four typical locations: Nanchong, Wuhan, Nanchang and Nanjing) for September to May or for Northern China (represented by two typical locations: Xining, Qinghai and Hailaer, Inner Mongolia) for April to September, 1971-2000. Source: China Climatic Data Center, National Meteorological Information Center, CMA (http://cdc.cma.gov.cn).

'Total precipitation, including snow, average of totals for Yangtze River region (represented by four typical locations: Nanchong, Wuhan, Nanchang and Nanjing) for September to May or for Northern China (represented by two typical locations: Xining, Qinghai and Hailaer, Inner Mongolia) for April to September, 1971-2000. Source: China Climatic Data Center, National Meteorological Information Center, CMA (http://cdc.cma.gov.cn).

rice or cotton crops usually follow oilseed rape over the summer months. Phoma stem canker caused by L. biglobosa has been found on both winter oilseed rape in provinces along the Yangtze river and spring oilseed rape in northern China.

There is evidence that L. maculans should be considered as a global invasive species (www.issg.org/database); it has recently spread across Canada (1975-1998), from the USA into Mexico (2001) and eastwards across Europe into Poland (1994-2007) into areas where only the less damaging L. biglobosa was previously present (Fitt et al., 2006a). If L. maculans is introduced into China through international trade and becomes established, then it will considerably impact on both cultivated and indigenous brassica species (Fig. 4). Crop losses in oilseed and vegetable brassicas will increase poverty and starvation for subsistence farmers. China is considered the centre of origin for B. rapa (Liu, 1985), one of the diploid progenitors of the allotetraploid $B$. napus, and $B$. rapa was cultivated there by 1500 BC (Prakash, 1980). Thus, introduction of L. maculans into China may also threaten related wild Brassica species and the wildlife which depends on them.

To quantify the risk posed by L. maculans to brassicas in China, there is a need to model, both biologically and economically, the risk of entry, establishment and spread of the pathogen, as for the potential spread of Tilletia indica (wheat karnal bunt) into Australia (Stansbury et al., 2002; Wittwer et al., 2005). Long-distance inter-continental spread of L. maculans is probably due to its transmission on seed of B. napus, B. rapa, B. oleracea and other brassica crops by international trade (Chigora \& Hall, 1995; West et al., 2001). However, L. maculans may also be spread in infected stem debris if this is transported over long distances (McGee \& Petrie, 1978). Wherever phoma stem canker occurs, the air-borne L. maculans ascospores are usually the main inoculum which spreads the disease over shorter distances into nearby crops (West et al., 2001). However, timing of ascospore discharge differs between locations and seasons. Differences in timing of maturity of pseudothecia on oilseed rape crop debris, which are related to weather factors, are the main cause of differences in the timing of the start of ascospore discharge (West et al., 1999; Huang et al., 2007). This paper reports work to quantify the risk to China from L. maculans, based on models fitted to data describing the spread across Canada, and to suggest strategies for preventing entry of the pathogen into and spread within China.

\section{Modelling and analysis}

\section{Spread of L. maculans across Canada}

Leptosphaeria maculans was first found in Canada in 1975 at Star City, north-east of Saskatoon in Saskatchewan province, where a severe epidemic of phoma stem canker had occurred on spring oilseed rape (Brassica napus) (McGee \& Petrie, 1978; Petrie, 1978). Over the next few years, L. maculans spread over oilseed rape 


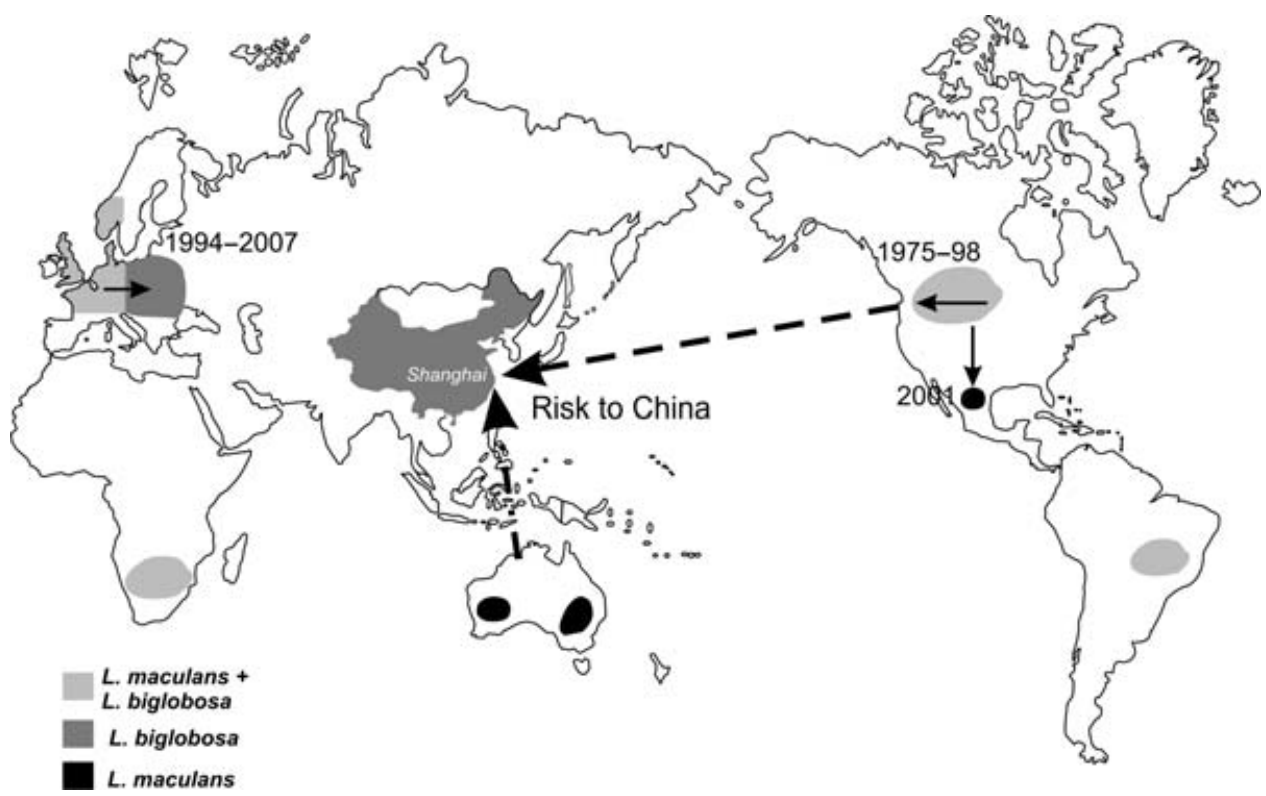

Figure 4 World-wide spread of Leptosphaeria maculans into areas where only L. biglobosa was present previously, in Canada (1975-98) and eastern Europe (1994-2007), and from North America to Mexico (2001). Areas where the populations are characterized as predominantly L. maculans, L. biglobosa or a mixture of the two species are indicated by patches with different shadings. There are other areas where there have been reports of the disease (sometimes only a single report) but the pathogen species has not been identified (Fitt et al., 2006a). There is a risk of spread of $L$. maculans into China, particularly on oilseed rape seed imported from Canada or Australia.

growing regions of Saskatchewan, where previously only L. biglobosa had been found and severe phoma stem canker epidemics had not occurred. Leptosphaeria maculans was first discovered in the neighbouring province of Alberta in 1983 in one oilseed rape crop near Lloydminster just across the provincial border from Saskatchewan (Kharbanda, 1993). In an attempt to prevent entry of the pathogen into Alberta (where only the less damaging L. biglobosa was present), the provincial government declared L. maculans as a pest under the Agricultural Pest Act, 1984. This Act provided legislative authority to Alberta Agriculture and Municipal Agricultural Services Boards to take necessary measures to control this pathogen, to prevent severe phoma stem canker epidemics like those that had occurred in Saskatchewan. Under the Act, transport of infected brassica seed across the provincial border into Alberta from Saskatchewan was banned. Whilst this short-term strategy may have delayed the entry of L. maculans into Alberta, nevertheless a severe epidemic of phoma stem canker associated with L. maculans occurred in 1988 at Lloydminster, Alberta.

Short-term strategies to impede the spread of L. maculans across Alberta also included the education of farmers and extension workers to recognise the symptoms of phoma stem canker. Staff at several private seed testing laboratories were trained to test oilseed rape seed for the presence of L. maculans to provide this service to the local seed crop growers (Kharbanda \& Stevens, 1993). To confirm the presence of L. maculans in a seed crop, a sample of 400 seeds was surface sterilized in $1 \% \mathrm{NaOCl}$ solution for 2 min and 25 seeds per plate were placed on either potato dextrose agar culture medium or sterile filter paper (moistened with $200 \mu \mathrm{g} \mathrm{mL} \mathrm{m}^{-1}$ streptomycin solution) in Petri dishes at about $23^{\circ} \mathrm{C}$, incubated for $48 \mathrm{~h}$ and then transferred to $-20^{\circ} \mathrm{C}$ for $24 \mathrm{~h}$. All dishes were transferred to a sporulation chamber fitted with NUV (360 nm) light for another 3 days, and then examined for the presence of $L$. maculans pycnidia. To confirm the presence of L. maculans, the pycnidial exudate was transferred to modified Czapek-Dox agar medium and incubated at $20^{\circ} \mathrm{C}$ for 5 days. Production of pinkish orange colour in the agar signified L. biglobosa; L. maculans does not produce any pigmentation. A certificate stating the seed tested was free from L. maculans was issued by the seed testing laboratory in cases where L. maculans was not found. Annual field surveys of oilseed rape crops were also done to measure the extent of the spread of the disease across Alberta.

As a long-term strategy, programmes to breed oilseed rape cultivars suitable for Canadian growing conditions with resistance to L. maculans were started at several universities, Agriculture Canada Research Stations and private companies across Canada. The Alberta Environmental Centre (now Alberta Research Council) provided isolates of several morphologically distinct types of L. maculans to different laboratories and participated in assessment of phoma stem canker on new breeding material in artificially inoculated or naturally infested field trials to confirm resistance. Resistance to L. maculans became a prerequisite for registration of new oilseed rape cultivars in western Canada from 1990 (Raymond Gaduoua, Western Canadian Canola/Rapeseed Recommending Committee, personal communication). Field trials testing resistance to L. maculans were started in 
1990 under the auspices of Western Canada Canola/ Rapeseed Recommending Committee, and in 1995 cultivars with resistance were first registered.

\section{Surveying spread of L. maculans across Canada} (Alberta province)

Spring oilseed rape crops (generally sown in May and harvested in September in Alberta, mean temperature $11 \cdot 1^{\circ} \mathrm{C}$, total rainfall $328 \mathrm{~mm}$ during growing season) (Table 1) were surveyed for the presence of $L$. maculans and incidence and severity of associated phoma stem canker epidemics in Alberta province from 1983 to 1998 after the extensive spread of L. maculans in Saskatchewan (McGee \& Petrie, 1978; Petrie, 1978). Samples were taken in July or August when crops were in late flowering or as stubble after harvest. From 1983 to 1986, crops were thoroughly surveyed in the east-central region of Alberta near Lloydminster, where L. maculans had been discovered in 1983 (Kharbanda, 1993). Plant pathologists examined 25-50 plants per crop sampled from five locations approximately $100 \mathrm{~m}$ apart along a 'W'-shaped path. Plants were uprooted and lower leaves and stems, particularly the crown region, were examined for the presence of pycnidia of L. maculans (which generally produces more pycnidia in lesions than L. biglobosa). Disease incidence ( $\%$ plants affected) data were collected. Severity of stem cankers caused by L. maculans was evaluated using a simple scale (trace - slight - moderate severe). Samples were taken to the laboratory to confirm the presence of L. maculans by isolation onto culture medium. In certain cases, presence of L. maculans was confirmed by inoculating young cotyledons of a susceptible cultivar (McGee \& Petrie, 1978; Kharbanda,1993; Williams \& Fitt, 1999). Cotyledons of 10-day-old seedlings were inoculated with a drop of L. maculans spore suspension containing about $10^{6}$ spores $\mathrm{mL}^{-1}$ in $0.5 \%$ gelatine solution. The pots were covered with a polyethylene bag to maintain high humidity for $48 \mathrm{~h}$, then incubated for 8 days at $23^{\circ} \mathrm{C}$ in controlled environment cabinets. The inoculated cotyledons were scored for disease symptoms; L. maculans caused extensive damage to the cotyledon tissue whereas L. biglobosa caused only slight necrosis around the inoculated site.

As L. maculans spread westwards and southwards across Alberta over the next 15 years, the extent of the survey was gradually expanded to include the whole of areas within which L. maculans was being found. In 1987, crops were sampled to confirm infection by L. maculans; one crop per 8094 ha in each crop district where oilseed rape was grown was surveyed. From 1988 to 1995, crops were randomly chosen within each crop district at a frequency of one crop per 2000 ha sown to oilseed rape. Cultivars resistant to L. maculans were introduced in Alberta at that time, and so the perceived threat from phoma stem canker disease decreased accordingly. Surveys were continued in districts that still placed a high priority on control of phoma stem canker, where the disease was severe or further spread of the disease was suspected (e.g. the Peace River region in north-west
Alberta). Additional survey data were collected from 1996 to 1998 as part of a larger coordinated oilseed rape disease survey done in Alberta, Saskatchewan and Manitoba provinces of Canada. Each provincial agronomist was asked to identify six crops in their area that represented the local range of cultivars, fertiliser inputs and other production practices. The presence or absence of phoma stem cankers on the stem bases or upper stems were recorded for each plant and these data were then used to calculate \% plants affected.

Modelling spread of L. maculans across Alberta, Canada Data from surveys in Alberta from 1983 to 1998 were collated to provide 4507 records for modelling spread of L. maculans across Canada. The main information used for modelling was the decimal latitude and longitude of each crop sampled and the presence/absence of L. maculans. The Peace river region data were excluded from the modelling since this region in north-west Alberta is not contiguous with the other main oilseed rape growing areas in central and south Alberta. A simulation model to describe spread of L. maculans across Alberta during the period 1983 to 1998, starting from the Lloydminster area in east-central Alberta, was constructed using these data and the statistical software package GenStat 5 (Payne et al., 2007).

First, before modelling began, all the data for the spread of L. maculans across Alberta between 1983 and 1998 were organised into spreadsheets and validated to ensure that they had been entered accurately. They were then plotted on a map of Alberta to show the spread of $L$. maculans southwards and westwards from east-central Alberta. The annual spread of L. maculans from one year to the next was summarized by calculating the mean and standard deviation latitude and longitude for sites with L. maculans for each year. Then the mean latitude and mean longitude of these sites were plotted against time (year) to show approximately the rate of spread of L. maculans across the province of Alberta. Linear regression of mean latitude and longitude on time (year) gave slopes (degrees per year) of $-0 \cdot 076$ (s.e. $0 \cdot 014$ ) and $-0 \cdot 152$ (s.e. 0.039), which describe the movement of L. maculans southwards and westwards across the province. These regressions accounted for 67.7 and $49.7 \%$, respectively, of the variance in the data. The range for latitude was much smaller than that for longitude, which probably explains the greater association with time of the latter. The longitudinal rate of spread was used in the simulation model.

To construct the simulation model, the spread of $L$. maculans from one site to another in successive years was estimated by assuming that the pathogen could spread only from the nearest site with $L$. maculans in the previous year. This relationship was described by a logistic regression with $0 / 1$ representing absence/presence of $L$. maculans and log-transformed minimum distance as the dependent variable. The probability $(p)$ that $L$. maculans spread from one infected site to a given site in the next season was related to the logarithm of minimum distance between the two sites as: 
$\log \operatorname{it}(p)=a+b \times \log ($ distance $)$

where

$$
\log \operatorname{it}(p)=\log \left(\frac{p}{1-p}\right)
$$

and $a$ and $b$ are coefficients. Since $b$ is negative and assumed to be the same for all years, the probability of spread decreases with increasing distance of the new site from the site with $L$. maculans the previous season. The coefficient $a$ describes the mean density of sites with L. maculans and was allowed to vary from year to year to account for seasonal differences in weather and agronomic conditions.

In the simulation model, the oilseed rape growing area of Alberta was described by a regular grid $(51 \times 41$ points) from 110 to 115 degrees longitude and 51 to 55 degrees latitude, in $0 \cdot 1$-degree intervals. Beginning with the single site (Lloydminster) with L. maculans in 1983, probabilities of spread for each year were evaluated according to the logistic regression model. Random probabilities $(0<p<1)$ that a point (site) on the grid had L. maculans were also generated for each point on the grid for each year. If the generated probability was less than the evaluated probability at the site, then it was designated as infected with L. maculans for that year. This simulation rapidly spread $L$. maculans in an unstructured

a
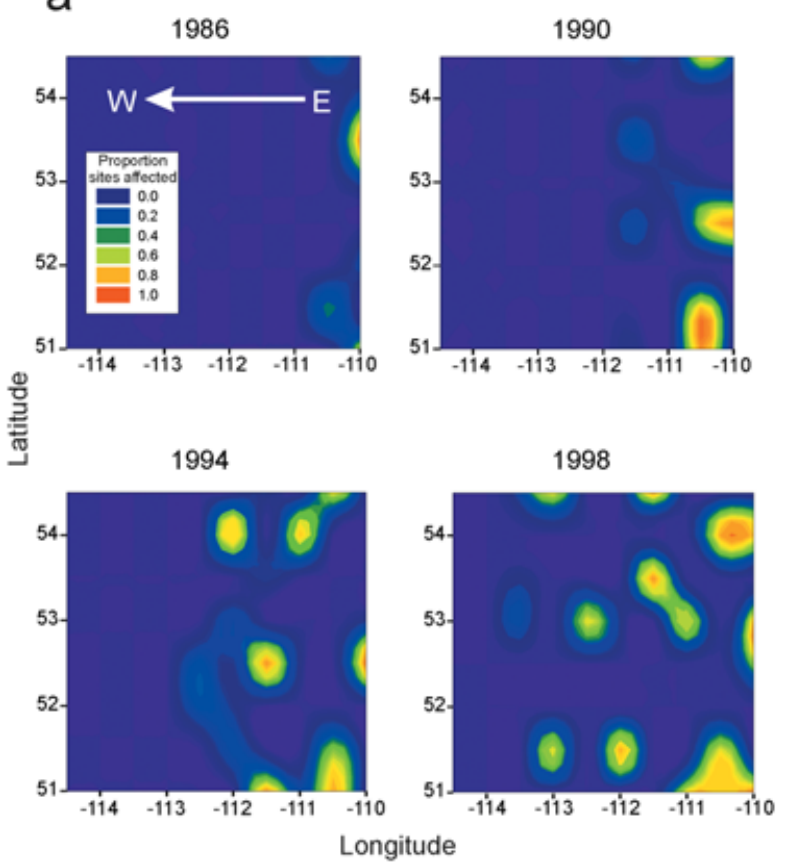

way over the grid representing Alberta. Therefore, the simulation model was modified to incorporate additional features based on the estimated rate of longitudinal spread across Alberta $(0.152$ degrees per year) and on the aggregation (patchiness) of disease development. The aggregation was incorporated by imposing patches (comprising 25 grid points) over the grid and allowing only a proportion $(0 \cdot 4)$ of patches to have L. maculans. Results showed that, over the 15-year period 1983 to 1998, the model predicted an increase in range (westwards) and density of L. maculans (Fig. 5a).

\section{Economic analysis of spread of L. maculans across}

Alberta, Canada

The output data from the model were used to estimate the cost of the damage caused by the disease epidemic. Since there was a policy of destroying affected crops, if a site was designated by the model as infected, then it was assumed that the crop at this site was lost for that year. Since the model provides data for the spread of $L$. $m a c u$ lans across Alberta and not data for actual sites, the total number of infected patches was divided by the total number of patches to estimate a percentage of the total crop lost to the epidemic each year.

Price data were taken from the Canola Council of Canada website (http://www.canola-council.org/) and then converted into 2006 US\$ dollars using historical

b
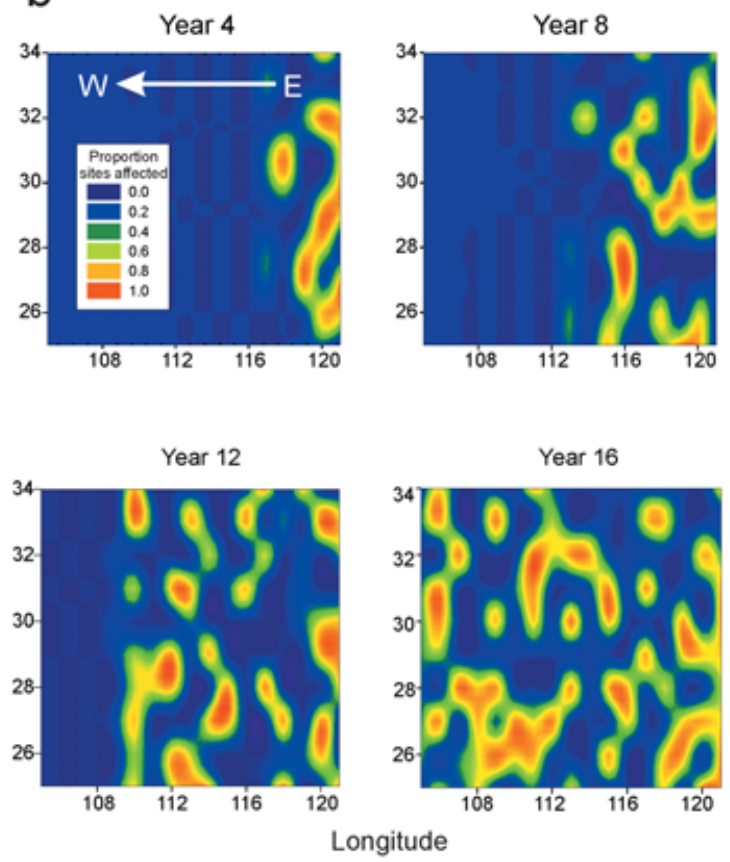

Figure 5 Modelling spread of Leptosphaeria maculans. (a) Westward spread of L. maculans across Alberta, Canada over the period 1983 to 1998 starting from Lloydminster on the Saskatchewan/Alberta border. Results presented indicate the proportion (0-1) of sites within a patch (out of 25 sites; i.e. 25 grid points) that are infected by L. maculans at 4-year intervals (1986, 1990, 1994, 1998). Each patch is taken as 0.5 degrees of latitude ( 5 points) $\times 0.5$ degrees of longitude ( 5 points). The oilseed rape growing area of Alberta is assumed to be from 51 to 54.5 degrees north and from 110 to 114.5 degrees west. (b) Potential westward spread of $L$. maculans across the oilseed rape growing area in the Yangtze river basin, China, over a 16 year period, with the epidemic assumed to start from Shanghai. Results presented indicate the proportion of sites within a patch (out of 25 sites) that are infected by L. maculans at 4-year intervals. Each patch is taken as 1 degree of latitude $\times 1$ degree of longitude. The oilseed rape growing area of the Yangtze river basin in China is assumed to be from 25 to 34 degrees north and from 105 to 122 degrees east. 
interest and exchange rates from the Bank of Canada (http://www.bankofcanada.ca). All price and cost figures are given in 2006 US dollars. The figures for the yield and area of oilseed rape in Alberta province were also taken from the Canola Council website. The area sown with oilseed rape $(1.55 \mathrm{M}$ ha) was multiplied by the average yield $\left(1.5 \mathrm{tha}^{-1}\right)$ and the yearly price to give the potential value of the Alberta crop for that year. The potential value of the Alberta crop was multiplied by the percentage of the crop lost to the disease to estimate the value of the crop lost to the disease. These calculations assume that the price of the oilseed rape is independent of the spread of the disease. It is possible that a reduced supply of oilseed rape and increased marginal cost of production, caused by the costs of the inputs into diseased, unproductive crops, will have caused the price to increase. However, since there was no statistical evidence to suggest such a correlation, one is justified in taking the price of oilseed rape as independent of the spread of the disease.

The spread of L. maculans across Alberta from 1983 to 1998 was therefore estimated to have caused a total loss of US\$2680 million, at an average loss of US\$167 million per year. The estimated losses for each year were summed to estimate the cumulative losses (estimated total value of output lost due to the disease) up to that year (Fig. 6a). Alberta oilseed rape had an average annual output of US $\$ 2000$ million over this period and thus the average loss of US\$167 million is a loss of $c a .8 \%$ each year. The
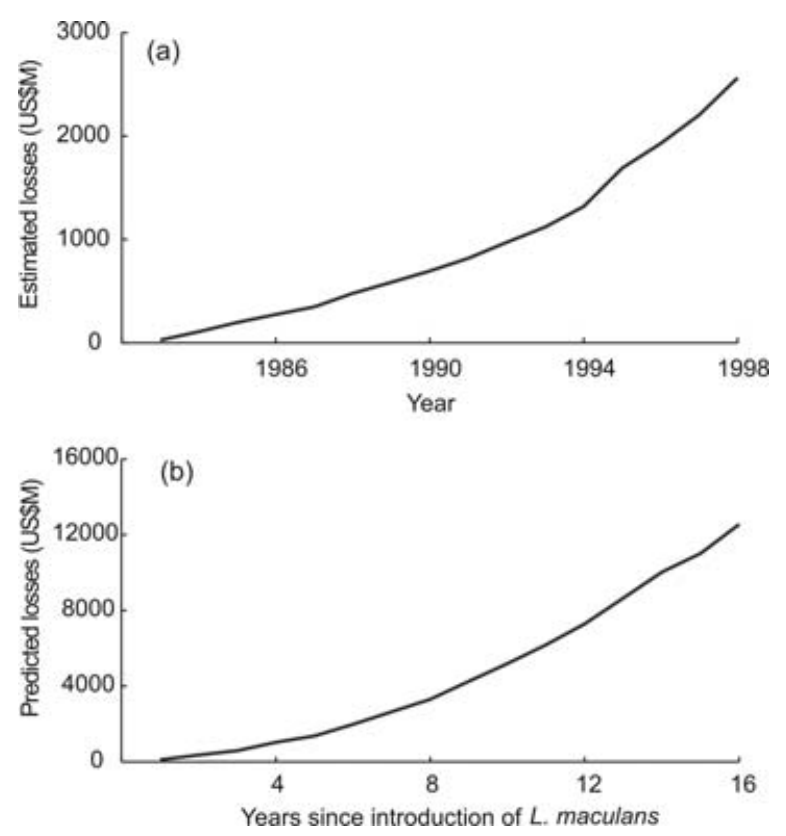

Figure 6 Cumulative financial losses from phoma stem canker in (a) Alberta province, Canada, estimated over the period 1983 to 1998; (b) China (Yangtze river basin) predicted over a 16 year period. All figures are given in million US dollars (\$USM), evaluated to 2006 prices and calculated using models for estimating/predicting the spread of the disease in space and time. Results presented indicate the total cost of the phoma stem canker epidemic up to the selected date. Estimated/ predicted losses for each year are given in Table 2.
Table 2 Estimated (Canada) or predicted (China) losses for phoma stem canker (Leptosphaeria maculans) epidemics for each year

\begin{tabular}{lll}
\hline & \multicolumn{2}{l}{ Losses (\$US million) $^{\mathrm{a}}$} \\
\cline { 2 - 3 } Year & Canada (1983-1998) & China (predicted) \\
\hline 1 & 48 & 111 \\
2 & 133 & 234 \\
3 & 137 & 212 \\
4 & 110 & 385 \\
5 & 97 & 276 \\
6 & 168 & 479 \\
7 & 133 & 497 \\
8 & 122 & 470 \\
9 & 132 & 646 \\
10 & 156 & 594 \\
11 & 147 & 614 \\
12 & 188 & 646 \\
13 & 345 & 758 \\
14 & 212 & 734 \\
15 & 240 & 496 \\
16 & 310 & 741 \\
Mean & 167 & 493 \\
\hline
\end{tabular}

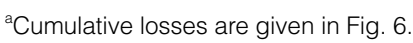

most serious estimated losses were in 1995 (US\$345 million, 21\%) and 1998 (US\$310 million, 20\%) (Table 2). The costs of the remedial strategies used in Alberta were minimal in relation to the cost of the damage caused. The cost of surveying the crops, gathering data on the spread of disease and doing laboratory diagnostics was estimated at US\$325000 each year, and the cost of breeding cultivars resistant to $L$. maculans was estimated at US\$70000 a year. Thus these outlays are negligible in comparison to the damage caused by the pathogen L. maculans spreading across Alberta. It was assumed that the economic cost of the disease was solely in terms of lost production. The overall economic effects will have been far greater, as the Canola Council of Canada estimates that the industry adds over US\$9700 million to the Canadian economy, over two thirds of this in Western Canada. This is greater than the value of the raw product due to other value-added activities, such as crushing and esterification, and also through taking advantage of export prices. Such effects have not been included in the economic analysis. Furthermore, these economic effects will be less in China, as China exports a far smaller percentage (less than $1 \%$ ) of its crop than Canada (75\%).

\section{Potential spread of L. maculans across China}

\section{Modelling potential entry and establishment of}

L. maculans in China

It is likely that L. maculans will enter China soon, since China has imported around 1.25 $\mathrm{M}$ tonnes of oilseed rape seed each year since 1998, mostly from Canada, and it has been estimated that the incidence of infected seed after harvest of Canadian oilseed rape is about $2 \%$ (Chigora $\&$ Hall, 1995). The probability of at least one failure to 
Table 3 The relationship between the mean number of Leptosphaeria maculans entries per shipment $\lambda$ under poor, average or good quarantine practice and the probability $P$ of one or more entries per year if there are five shipments per year into China

\begin{tabular}{lll}
\hline Quarantine & $\lambda$ & $P(1$ or more entries $)$ \\
\hline Poor & 1 & 0.632 \\
Average & 0.1 & 0.095 \\
Good & 0.01 & 0.010 \\
\hline
\end{tabular}

identify contaminated seed during quarantine inspection is derived from a Poisson distribution (Stansbury et al., 2002). Consider three possibilities corresponding to good, average and poor quarantine practice, the associated probabilities of at least one entry event $\lambda$ are the mean number of entries per shipment (Table 3). Assuming there are five shipments of seed per year, it is expected under poor quarantine management that infected seed will enter China every time. Under average and good quarantine practice, the expected numbers of entries are one entry every 2 years and one entry every 20 years.

However, the risk posed by this imported seed is initially small because it is used for crushing as a source of oil, rather than for planting. Nonetheless, problems will occur when the seed is transported away from the port of entry. Loss of seed is most likely to arise from a transport spillage or from the cleaning of ship holds. The likelihood of establishment of feral oilseed rape from transport spillages has been estimated to be very high near a delivery confluence point (Crawley \& Brown, 1995), with enough spillages to leave only $42 \%$ of patches examined free of oilseed rape plants in two successive years and for $22 \%$ of patches to be covered in both years. It has also been shown that about $15 \%$ of feral oilseed rape populations in any single year arise from transport spillages (Pivard et al., 2007). The location examined by Crawley \& Brown was around the Erith crushing plant in Kent, UK. Here, Archer Daniels Midland (ADM) claims to crush about two-thirds of the UK oilseed rape production. With around 500000 ha of oilseed rape grown in 2006, and an average yield of $3 \mathrm{t} \mathrm{ha}^{-1}$, this represents a crushing capacity of one million tonnes. This capacity is similar to China's annual imports of oilseed rape. That such large, dense oilseed rape populations were found on UK motorway verges suggests that it is likely that significant feral oilseed rape populations have entered China from Canadian seed. The probability of entry will be associated with the number of deliveries, which number around 50000 a year assuming that the imported seed is collected by articulated lorries with a $25 \mathrm{t}$ capacity. As imported seed reaches China at its east coast ports, it is near them that establishment of an infected crop would first occur.

The probability of the establishment of L. maculans in Chinese oilseed rape crops is more difficult to assess since there is little information about possible transmission of L. maculans from the infected seed or feral plants to contaminate crops; the probability of such transmission is likely to be small since the main method of dispersal of L. maculans is as wind-borne ascospores produced on crop debris (Fitt et al., 2006a). If seed is dispersed after a spillage within the port, a viable population of diseased plants may be established. Air-borne dispersal of ascospores from stem debris after senescence of the diseased plants may occur when conditions favour their transport and deposition. The quantity of diseased stem debris may be enough to provide a source for the ascospores to disperse. However, these ascospores are unlikely to infect the Chinese oilseed rape crops in the Yangtze river valley unless such dispersal occurs in October/November, when crops are at the susceptible seedling stage; if crops were infected in autumn, there would be sufficient time for phoma stem cankers to develop before harvest the following spring. The two factors which lead to establishment of the disease, presence of diseased stem debris and occurrence of favourable weather conditions, are considered independent.

This means that the separate probabilities can be multiplied together. Let $p_{m}$ be the probability of diseased stem debris being present and $p_{w}$ be the probability of favourable weather conditions. This gives the probability of establishment $p_{e}$ as $p_{e}=p_{m} p_{w}$. Different combinations of the probabilities for diseased stem debris and favourable weather conditions will give the same probability of establishment. The geometric distribution was used to estimate the probability $p_{f}$ of a number of failures $n_{f}$ before a successful establishment as:

$$
p_{f}=p_{e}\left(1-p_{e}\right)^{n f}
$$

The mean number of events before establishment is therefore $\left(1-p_{e}\right) / p_{e}$. If $p_{e}$ is small, then the probability of early establishment is correspondingly small since the expected number of failures will be large. Conversely, if $p_{e}$ is large (greater than 0.5 ), then the probability of early establishment will be large since the expected number of failures will be small. For example, if $p_{e}$ is $0 \cdot 1$, then the time from entry to establishment is $\left(1-p_{e}\right) / p_{e}=0 \cdot 9 / 0 \cdot 1=9$ years.

\section{Modelling potential spread of L. maculans across China (Yangtze river basin)}

Assuming that pathogen entry and establishment have occurred, the model used to describe the spread across Alberta was then adapted to predict the westward spread of L. maculans across oilseed rape growing regions of China from a point on the east coast (Shanghai, assuming that L. maculans is introduced into China on imported seed). This modelling also assumes that the rate of spread across the winter oilseed rape growing area in China can be estimated using the model developed for a spring oilseed rape growing area in Canada; whilst the adaptability of the pathogens suggests that they can cause serious losses on both crop types in climates similar to those in China, there are no precise data on rates of spread of L. biglobosa in Chinese crops. The simulation model was used to predict the spread of L. maculans across the southern (Yangtze river) oilseed rape growing area in China. This was represented by a rectangular grid $(106 \times 46$ points) covering the area 100 to 121 degrees of longitude and 24 to 33 degrees of latitude, with $0 \cdot 2$-degree intervals 
between grid lines. There was assumed to be a single initial source site at the far eastern edge of the grid (near Shanghai). The simulation model predicted that $L$. maculans would spread longitudinally (westward) in 16 years when the rate of spread was set at 0.75 degrees per year plus a small random uniform component. Three scenarios were then chosen to represent different densities of L. maculans that were obtained by using different values of the coefficient $a$, taken from the model derived from the Canadian survey data for 1994, 1995 and 1996, respectively. This part determines the density of spread of L. maculans $(a)$ within each patch, even though the probability of spread of L. maculans is a function of the proximity to a site with $L$. maculans in the previous year. A longitudinal boundary was set, beyond which it was assumed the annual spread of L. maculans was not possible. Finally, the probability of selecting a patch at random within that boundary was set at 0.5 for each year. Roguing (destruction) of infected crops was also incorporated for single site patches when there were sufficient patches with more than five sites with $L$. maculans. Results show the gradual increase in range (westwards) and density of $L$. maculans over the 16 year period (Fig. $5 \mathrm{~b}$ ).

\section{Strategies to prevent/impede spread of $\mathrm{L}$. maculans intolacross China}

Since Chinese cultivars of oilseed rape (B. napus) are extremely susceptible to $L$. maculans when they are grown in Europe or Australia (Fitt et al., 2006a,b), there is a need to develop strategies to prevent spread of L. maculans into China. Provided that strategies adopted to prevent spread of L. maculans within China are similar to those used in Canada (where affected crops were destroyed), the simulation model predicts that it will take several years for L. maculans to spread westwards across China. This should allow sufficient time for a combination of short-term strategies to prevent spread of $L$. maculans into China, medium-term strategies to prevent spread within China and long-term strategies to increase the resistance of Chinese cultivars to L. maculans.

Short-term strategies to prevent entry and establishment of L. maculans in China include: (i) a Pest Risk Analysis for L. maculans by Chinese quarantine scientists to determine the risk that it will enter China and become established; (ii) workshops to train research/quarantine scientists in PCR diagnostics to detect L. maculans (Liu et al., 2006) in imported seeds; (iii) workshops/manuals to train research/extension scientists to recognise symptoms of phoma stem canker (West et al., 1999, 2001) on wild and cultivated brassicas, and identify L. maculans or L. biglobosa by PCR or isolation of cultures (Williams \& Fitt, 1999; West et al., 2002a); (iv) a survey to describe the distribution of L. biglobosa and confirm that L. maculans is still not present in China; (v) workshops with policymakers about risks from L. maculans and strategies to prevent spread in China; (vi) information about the pathogen, disease and strategy publicized throughout China, using TV, radio, newspapers, newsletter, internet and multimedia facilities; and (vii) a regional coordination mechanism so that samples with possible $L$. maculans can be passed from community and farmer groups to diagnostic centres, with guaranteed feedback for test results.

Medium-term strategies to prevent spread within China include assessment of Chinese cultivated and wild brassicas for resistance to L. maculans (Delourme et al., 2006). Use of resistant cultivars is a major potential strategy for plant disease control for subsistence farmers in China. This would decrease crop damage, prevent starvation and poverty, and delay disease spread, especially to natural ecosystems where brassica diversity is rich. There is a need to train Chinese researchers, in Europe, Canada or Australia, about: (i) epidemiological differences between L. maculans and L. biglobosa in survival on debris, infection of leaves and spread to stems (Fitt et al., 2006c); and (ii) screening Chinese crop cultivars and key biodiversity indicator species of non-crop brassicas for sources of resistance to L. maculans. Chinese researchers can then share this knowledge to help disseminate information to community groups in China. Long-term strategies include the introduction of durable resistance to L. maculans into Chinese brassica breeding lines.

Economic analysis of potential spread of $\mathrm{L}$. maculans across China (Yangtze river basin)

The potential costs of a L. maculans epidemic to producers in the Yangtze river basin of China were predicted using the methods for estimating the economic losses in Alberta, Canada, by providing present value estimates of the value of the crop designated as infected by the model. The area of oilseed rape cultivated in the Yangtze river basin is approximately $7 \mathrm{M} \mathrm{ha}$ and the average yield is approximately $2 \cdot 25 \mathrm{tha}^{-1}$. The economic analysis of the spread of the epidemic in China differs in the use of prices from that in Canada. Since no future price data are available, the price per tonne of oilseed rape was assumed to be US $\$ 320$ (current price in China). Furthermore, the predictions are discounted assuming a constant interest rate of $5 \%$. The prices have not been adjusted for inflation since China's inflation rate is difficult to predict, and thus it is assumed that all relevant price indices change together, so that the inflation rate is nominally irrelevant.

The figures for the area, price and yield were multiplied to estimate Chinese annual oilseed rape output as currently being worth US\$5040 million. The predicted losses for each year were summed to show the cumulative losses and estimate the total value of output lost due to the disease up to that year (Fig. 6b). The economic analysis predicts a total loss of US $\$ 7900$ million over a 16 year period from the start of the epidemic, at an average annual loss US\$495 million (ca. 16\%). The greatest losses estimated were in the thirteenth (US\$760 million, 27\%) and sixteenth years (US\$740 million, 31\%) (Table 2). In addition to the monetary loss caused by the spread of L. maculans along the Yangtze river valley, the loss of such an important crop will significantly harm farm incomes. If farmers were to lose $30 \%$ of their crop in one year, as the model predicts for the sixteenth year, then many farmers, especially those working on marginal incomes, would be unable to 
continue to support their families. Furthermore, the longterm persistence of the disease will have a permanent impact on farm incomes.

Incorporating the risk of entry and establishment, the present value of damage caused by the predicted phoma stem canker epidemic in China is US\$5090 million under poor quarantine procedures, US\$4620 under average quarantine procedures and US\$1920 under good quarantine procedures. If $L$. maculans enters immediately, then the predicted damage is US\$7900 million. For poor quarantine procedures, it is assumed the disease epidemic starts in 9 years time (2017), as estimated, and the losses are further discounted at the $5 \%$ interest rate to provide the predicted present value of the damage the disease will cause. Thus China can expect the disease to reduce output by more than US\$5000 million if no action is taken. Similarly, with average or good quarantine procedures, the start dates of the epidemic are predicted to be in 11 years time (2019) or in 29 years time (2037) respectively. Thus enforcing strict quarantine procedures will postpone the start of the epidemic and save billions of dollars in present value terms.

The short-term strategy of testing imported seed for L. maculans to delay its introduction into China will cost about US $\$ 22500$ per year (Table 4), with a moderate sample size tested. Educating farmers to recognise symptoms of the disease and surveying oilseed rape growing areas of China for crops affected by phoma stem canker to decrease the rate of spread within China will cost an estimated US\$20000 per year. The long-term strategy of breeding Chinese cultivars with resistance to L. maculans, including trials done outside China in countries where L. maculans is already present, is likely to cost US\$43000 per year over a 10 year period. These costs are minimal in relation to the potential losses caused by the phoma stem canker disease epidemic in China. The economic losses can be minimized by decreasing the lag time between the arrival of L. maculans in China and the introduction of resistant cultivars. This lag time can be decreased by starting disease resistance breeding programmes earlier. It is this lag time that is the decision variable over which the Chinese government has control.

\section{Discussion}

This work suggests that there is a serious, if small, risk that L. maculans will enter and become established in
China, since China imports seed of oilseed rape from Canada where seed-borne infection by L. maculans does occur (Chigora \& Hall, 1995). Furthermore, Chinese cultivars of oilseed rape are highly susceptible to $L$. maculans (Fitt et al., 2006a) and the occurrence of L. biglobosa in China (West et al., 2000) suggests that the agronomic and environmental conditions there will also be favourable for L. maculans, which occupies a similar ecological niche (Fitt et al., 2006c). Should L. maculans become established in China, the experience from Canada and Poland (Fitt et al., 2006a) suggests that there is a high probability that it will spread, despite strategies to contain it (Kharbanda, 1993). Furthermore, Chinese government policies to decrease air pollution, involving the banning of burning of crop debris by farmers, may increase the amount of inoculum available. This is likely to have serious economic consequences for Chinese farmers and pose a threat to related wild brassicas and the wildlife they support. Furthermore, with predicted climate change, the severity of epidemics may increase (Evans et al., 2008).

By comparison with the costs of a phoma stem canker epidemic in China, the costs of strategies to prevent entry and spread of L. maculans are very small. As with strategies to prevent spread of T. indica into Australia (Stansbury et al., 2002), the most cost-effective strategies may be those to decrease the risk of entry and establishment of L. maculans in China. For example, it should be possible for China to import oilseed rape oil rather than seed from Canada. If seed is imported, then improvements to handling of cargoes and quarantine procedures will greatly decrease the risk of entry. Furthermore, with the development of L. maculans-specific PCR diagnostics (Liu et al., 2006) screening of seed for L. maculans is now much easier than when the Canadian epidemic occurred (Kharbanda \& Stevens, 1993), although it might take more than 1 year to introduce such a strategy (Table 4). Extreme vigilance must be employed to ensure that no oilseed rape debris is imported into China, since infected debris would provide a much more potent source of L. maculans inoculum than infected seed. Such infected debris may have been responsible for spreading $L$. maculans into Canada (McGee \& Petrie, 1978).

If $L$. maculans does become established in China, the Canadian experience suggests that surveys, education of farmers and destruction of affected crops is unlikely to eliminate spread of the pathogen, although such strategies may delay its spread. Such strategies can be implemented

Table 4 Strategies to decrease the risk of entry of Leptosphaeria maculans into China or decrease the risk of spread within China in relation to the estimated time from a decision to implementation, effect and cost of the strategy

\begin{tabular}{lccc}
\hline Strategy & $\begin{array}{l}\text { Time from decision to } \\
\text { implementation (months) }\end{array}$ & $\begin{array}{l}\text { Time from implementation } \\
\text { to effect (years) }\end{array}$ & Effect \\
\hline Test imported seed & $12-18$ & 0 & Reduce risk of entry \\
Educate farmers & 4 & 5 & Decrease spread \\
Survey for disease & 4 & 2 & Decrease spread \\
Destroy affected crop & 3 & 0 & Decrease spread \\
Breed disease resistance & $18-24$ & 10 & Decrease loss, diminish spread \\
\hline
\end{tabular}


quickly (Table 4). The most effective long-term strategy will be to introduce resistance to L. maculans into Chinese breeding lines and cultivars. Experience in Australia and France suggests that introduction of major gene resistance will not provide durable resistance (Rouxel \& Balesdent, 2005; Sprague et al., 2006). Although more difficult and time-consuming, it is advisable to introduce into Chinese cultivars the polygenic resistance which is present in European winter oilseed rape cultivars (Fitt et al., 2006a). However, since resistance breeding is a long-term strategy (Table 4), such a breeding programme needs to be started as soon as possible. A combination of such short-term, medium-term and long-term strategies to prevent entry of L. maculans into China and spread within China will involve collaboration between policy makers, researchers, extension workers and farmers.

\section{Acknowledgements}

We are grateful for funding from the UK Biotechnology and Biological Sciences Research Council, Department for Environment, Food and Rural Affairs, Royal Society, DFID/British Council (Development Partnerships in Higher Education), British Society for Plant Pathology, Alberta Research Council and Chinese Ministry of Agriculture. We thank the many people who were responsible for collecting the Alberta survey data used in this paper and Julie and Katy Steed who collated the data in an electronic format from the original paper records. We thank Andrew Barnes and Dominic Moran for advice on the economic analyses and the following for providing Figures: Qiangsheng Li for Fig. 1a \& b; Jon West for Fig. 1c; Ze Liu for Fig. 2; Yong-Ju Huang for Fig. 3a.

\section{References}

Biddulph JE, Fitt BDL, Leech PK, Welham SJ, Gladders P, 1999. Effects of temperature and wetness duration on infection of oilseed rape leaves by ascospores of Leptosphaeria maculans (stem canker). European Journal of Plant Pathology 105, 769-81.

Chigora JL, Hall R, 1995. Relationships among measures of blackleg in winter oilseed rape and infection of harvested seed by Leptosphaeria maculans. Canadian Journal of Plant Pathology 17, 25-30.

Crawley MJ, Brown SL, 1995. Seed limitation and the dynamics of feral oilseed rape on the M25 motorway. Proceedings of the Royal Society, Series B 259, 49-54.

Delourme R, Chevre AM, Brun H et al., 2006. Major gene and polygenic resistance to Leptosphaeria maculans in Brassica napus. European Journal of Plant Pathology 114, 41-52.

Evans N, Baierl A, Semenov MA, Gladders P, Fitt BDL, 2008. Range and severity of a plant disease increased by global warming. Journal of the Royal Society Interface 5, 525-31.

Fitt BDL, Brun H, Barbetti MJ, Rimmer SR, 2006a. World-wide importance of phoma stem canker (Leptosphaeria maculans and L. biglobosa) on oilseed rape (Brassica napus). European Journal of Plant Pathology 114, 3-15.

Fitt BDL, Evans N, Howlett BJ, Cooke BM, 2006b. Sustainable Strategies for Managing Brassica napus Resistance to
Leptosphaeria maculans (Phoma Stem Canker). Dordrecht, the Netherlands: Springer.

Fitt BDL, Huang YJ, van den Bosch F, West JS, 2006c. Coexistence of related pathogen species on arable crops in space and time. Annual Review of Phytopathology 44, $163-82$.

Huang YJ, Toscano-Underwood C, Fitt BDL et al., 2001. Effects of temperature on germination and hyphal growth from ascospores of A-group and B-group Leptosphaeria maculans (phoma stem canker of oilseed rape). Annals of Applied Biology 139, 193-207.

Huang YJ, Toscano-Underwood C, Fitt BDL, Hu XJ, Hall AM, 2003a. Effects of temperature on ascospore germination and penetration of oilseed rape (Brassica napus) leaves by A-group or B-group Leptosphaeria maculans (phoma stem canker). Plant Pathology 52, 245-55.

Huang YJ, Fitt BDL, Hall AM, 2003b. Survival of A-group and B-group Leptosphaeria maculans (phoma stem canker) ascospores and mycelium on oilseed rape stem debris. Annals of Applied Biology 143, 359-69.

Huang YJ, Fitt BDL, Jedryczka M et al., 2005. Patterns of ascospore release in relation to phoma stem canker epidemiology in England (Leptosphaeria maculans) and Poland (L. biglobosa). European Journal of Plant Pathology 111, 263-77.

Huang YJ, Liu Z, West JS, Todd AD, Hall AM, Fitt BDL, 2007. Effects of temperature and rainfall on date of release of ascospores of Leptosphaeria maculans (phoma stem canker) from winter oilseed rape (Brassica napus) debris in the UK. Annals of Applied Biology 151, 99-111.

Kharbanda PD, 1993. Blackleg of Canola in Alberta: Investigations on the Biology, Epidemiology and Management. Vegreville, Canada: Alberta Environmental Centre, AECV93-R5.

Kharbanda PD, Stevens RR, 1993. Seed Testing for Blackleg of Canola. Vegreville, Canada: Alberta Environmental Centre, AECV93-E1.

Liu HL, 1985. Genetics and Breeding of Oilseed Rape. Beijing, China: China Agricultural University Press.

Liu SY, Liu Z, Fitt BDL et al., 2006. Resistance to Leptosphaeria maculans (phoma stem canker) in Brassica napus (oilseed rape) induced by L. biglobosa and chemical defence activators in field and controlled environments. Plant Pathology 55, 401-12.

McGee DC, Petrie GA, 1978. Variability of Leptosphaeria maculans in relation to blackleg of oilseed rape. Phytopathology 68, 625-30.

Payne RW, Harding SA, Murray DA et al., 2007. The Guide to GenStat Release 10, Part 2: Statistics. Oxford, UK: VSN International.

Petrie GA, 1978. Occurrence of a highly virulent strain of blackleg (Leptosphaeria maculans) on rape in Saskatchewan (1975-77). Canadian Plant Disease Survey 58, 21-5.

Pivard S, Adamczyk K, Lecomte J et al., 2007. Where do the feral oilseed rape populations come from? A large-scale study of their possible origin in a farmland area. Journal of Applied Ecology, [doi:10.1111/j.1365-2664.2007.01358.x].

Prakash S, 1980. Cruciferous oilseeds in India. In: Tsunoda S, Hinata K, Gomez-Campo C, eds. Brassica Crops and Wild Allies: Biology and Breeding. Tokyo: Japan Scientific Societies Press, 151-63. 
Rimmer SR, van den Berg CGJ, 2007. Blackleg (phoma stem canker). In: Rimmer SR, Shattuck VI, Buchwaldt L, eds. Compendium of Brassica Diseases. St Paul, MN, USA: APS Press, 19-22.

Rouxel T, Balesdent MH, 2005. The stem canker (blackleg) fungus, Leptosphaeria maculans, enters the genomic era. Molecular Plant Pathology 6, 225-41.

Shoemaker RA, Brun H, 2001. The teleomorph of the weakly aggressive segregate of Leptosphaeria maculans. Canadian Journal of Botany 79, 412-9.

Sprague SJ, Balesdent MH, Brun H et al., 2006. Major gene resistance in Brassica napus (oilseed rape) is overcome by changes in virulence of populations of Leptosphaeria maculans in France and Australia. European Journal of Plant Pathology 114, 33-40.

Stansbury CD, McKirdy SJ, Diggle AJ, Riley IT, 2002. Modeling the risk of entry, establishment, spread, containment and economic impact of Tilletia indica, the cause of karnel bunt of wheat, using an Australian context. Phytopathology 92, 321-31.

Sun P, Fitt BDL, Steed JM, Toscano-Underwood C, West JS, 2001. Factors affecting development of phoma canker (Leptosphaeria maculans) on stems of winter oilseed rape (Brassica napus) in southern England. Annals of Applied Biology 139, 227-42.

Toscano-Underwood C, West JS, Fitt BDL, Todd AD, Jedryczka M, 2001. Development of phoma lesions on oilseed rape leaves inoculated with ascospores of A-group or B-group Leptosphaeria maculans (stem canker) at different temperatures and wetness durations. Plant Pathology 50, $28-41$.

Toscano-Underwood C, Huang YJ, Fitt BDL, Hall AM, 2003.
Effects of temperature on maturation of pseudothecia of Leptosphaeria maculans and L. biglobosa on oilseed rape stem debris. Plant Pathology 52, 726-36.

West JS, Biddulph JE, Fitt BDL, Gladders P, 1999. Epidemiology of Leptosphaeria maculans in relation to forecasting stem canker severity on winter oilseed rape in the UK. Annals of Applied Biology 135, 535-46.

West JS, Evans N, Liu S, Hu B, Peng L, 2000. Leptosphaeria maculans causing stem canker of oilseed rape in China. Plant Pathology 49, 800.

West JS, Kharbanda P, Barbetti MJ, Fitt BDL, 2001. Epidemiology and management of Leptosphaeria maculans (phoma stem canker) in Australia, Canada and Europe. Plant Pathology 50, 10-27.

West JS, Balesdent MH, Rouxel T et al., 2002a. Colonisation of winter oilseed rape tissues by $\mathrm{A} / \mathrm{Tox}^{+}$and $\mathrm{B} / \mathrm{Tox}^{0}$ Leptosphaeria maculans (phoma stem canker) in France and England. Plant Pathology 51, 311-21.

West JS, Fitt BDL, Leech PK, Biddulph JE, Huang YJ, Balesdent MH, 2002b. Effects of timing of Leptosphaeria maculans ascospore release and fungicide regime on phoma leaf spot and phoma stem canker development on winter oilseed rape (Brassica napus) in southern England. Plant Pathology 51, 454-63.

Williams RH, Fitt BDL, 1999. Differentiating A and B groups of Leptosphaeria maculans, causal agent of stem canker (blackleg) of oilseed rape. Plant Pathology 48, 161-75.

Wittwer G, McKirdy S, Wilson R, 2005. Regional economic impacts of a plant disease incursion using a general equilibrium approach. Australian Journal of Agricultural and Resource Economics 49, 75-89. 